\title{
Premature aging in adults with Down syndrome: genetic, cognitive and functional aspects
}

\section{Abstract}

Objective: To describe genetic aspects and characteristics associated with premature aging in adults with Down syndrome. Method: A cross-sectional study was carried out of 28 individuals with Down syndrome, aged between 20 and 54 years old (13 women and 15 men), in a university community genetics program, who were referred by philanthropic institutions which offers support to people with disabilities and their families. The genetic and functional data were recorded in anamnesis forms. Results: Karyotype analysis revealed free trisomy 21 , with only one hereditary case of translocation between chromosomes $15 / 21$. In the sample group, functional difficulties were observed in locomotion, sedentary lifestyles, behavior disorders, memory loss and depression symptoms, as well as loss of autonomy at more advanced ages. Only three people had reading and writing skills and 16 had good social relationships and friend-making skills. Conclusion: The study confirms that premature aging in Down syndrome starts in adulthood, and therapeutic followup is recommended with the implementation of interventions to prevent deficits and stimulate cognition, and activities for quality of life.

\footnotetext{
Universidade Federal da Bahia, Instituto de Biologia, Programa Genética\&Sociedade. Salvador, BA, Brasil.

2. Universidade Federal da Bahia, Instituto de Psicologia, Salvador, BA, Brasil.

The authors declare that there are no conflicts of interest in relation to this study. No funding was provided for this study.

Correspondence

Lília Maria de Azevedo Moreira' $\mathbb{D}$ Renata Melo dos Santos' (ID Marise Souza Barbosa² ${ }^{\mathbb{D}}$ Mônica Jacobina Fonseca Vieiral ${ }^{\mathbb{D}}$ Wiliane Santos de Oliveira $^{2} \mathbb{D}$

Keywords: Down Syndrome. Aging Premature. Neurodegerative Process. 


\section{INTRODUCTION}

Down syndrome (DS) or chromosome 21 trisomy is the main genetic cause of intellectual disability, which in Brazil occurs in about one in 600 to 800 births $^{1}$. Although there are hereditary cases, chromosomal disorders are most often due to a new mutation, with no chance of recurrence in the same family. Free trisomy of chromosome 21 is the most frequent disorder in the syndrome, occurring in 90 to $95 \%$ of cases. The remaining percentage is attributed to trisomy 21 by mosaicism, with normal and trisomic cells, Robertsonian translocations, half of which are hereditary, or to rarer chromosomic rearrangements with chromosome 21 .

DS is characterized by a variable degree of intellectual and motor developmental delay, a typical face profile and congenital, cardiac and systemic malformations, with severe or detrimental consequences, although there are differences in clinical signs according to ethnicity ${ }^{2}$.

As the individual grows older premature aging is observed, leading to senescence of the organs, immune system, strength and functional capacity. The changes caused by aging may potentiate the effects of trisomy, resulting in an even greater dependence on third parties for the performance of daily activities ${ }^{3}$. Such conditions eventually differentiate the aging process in individuals with and without DS 4 . Premature aging is accompanied by the whitening or loss of hair, hearing difficulties, reduced vision, cataracts, and manifestations of Alzheimer's disease (AD) ${ }^{5}$.

Hithersay et al. ${ }^{6}$ emphasize the role of AD in the life expectancy of people with DS, noting that this disorder occurs in about $70 \%$ of cases and that the mortality rate is about five times higher in those with dementia, whereas in the general population, dementia of either type is recorded on only $18 \%$ of death certificates in elderly persons over 65 years of age. This relationship between $\mathrm{AD}$ and $\mathrm{DS}$ occurs due to the influence of genes located in chromosome 21.

Among the gene products contained in this chromosomal region is APP (amyloid precursor protein), which is associated with poor cell adhesion, neurotoxicity and cell growth, with the early formation of diffuse plaques characteristic of AD. Arking ${ }^{7}$ notes that although APP production is greater in DS, different genetic mechanisms appear to control the formation of neuritic plaques both in this syndrome and in $\mathrm{AD}$, reinforcing the view that similar manifestations may be produced by different processes. According to Hopkins ${ }^{8}$, the signs and symptoms of DS can be explained by subtle changes in the pace of development induced by chromosomal imbalances, with other genes included in this process, which makes the understanding of premature aging in this syndrome complex.

With advances in medical treatments and early intervention therapies, the mortality rate of the syndrome has been reduced, with significant advances in physical and mental development. On the other hand, there is still a shortage of AD-focused intervention therapies in people with DS ${ }^{9}$. Research involving adults with DS and their interactions is therefore necessary, especially due to the particular health needs of this group ${ }^{10}$.

According to Rosa ${ }^{3}$, the recognition of premature aging in people with DS by society and public agencies may provide better planning of actions in several areas: preventive and curative medicine, psychology and gerontology, leading to new opportunities for social inclusion.

The etiological relationship of 21 trisomy with premature aging in DS remains unclear, which makes further studies on this topic necessary to support preventive measures and provide greater support to people with the syndrome at this stage of life. Considering the current trend of increased life expectancy in individuals with DS, the present study aimed to describe genetic aspects and characteristics associated with premature aging in Down syndrome.

\section{METHOD}

A cross-sectional descriptive study was carried out with a sample of 28 individuals aged between 20 and 54 years, who were treated from 2008 to 2018 at a university community genetics program that studied the karyotype and/or family genetic orientation, and who were invited from three non-profit institutions (named in this study as A, B, and C). We included 
all individuals with DS in the adult phase, referred by the partner institutions, based on literature ${ }^{3}$ that establishes that is possible to identify characteristics of premature aging in this syndrome from 25 years of age onwards. The most common type of care sought at the aforementioned health service is for children with suspected genetic syndromes, but the search for genetic guidance for adults and the elderly, although less frequent, made the present study possible.

Institution $\mathrm{A}$ is a social organization (NGO) and provides educational and psycho-pedagogical services for people with disabilities, while Institution $\mathrm{B}$ is a government-run special education center. Institution C, meanwhile, is non-profit and operates near a health center offering housing to people with disabilities who were abandoned by their families.

The participants of this study had the diagnosis of DS confirmed by the study of karyotypes, performed by the usual technique of lymphocyte culture and analysis under microscope following GTG banding, according to the norms recommended by An International System for Human Cytogenomic Nomenclature (ISCN) 2016 ${ }^{11}$.

Within the protocol of genetic care, anamnesis forms were complete with a record of the family's genetic history and pre, peri and postnatal data. The follow-up period was analyzed based on anamnesis records, with observations recorded in the periodic returns. The bases of interest in the consultation were aspects of overall health, cognition, functionality, behavior and social interaction. To this end, the form used for data collection was supplemented with a questionnaire prepared by the program, regarding the aspects of interest, which was answered by parents/guardians. Data collected on the first visit were described and then tabulated using Graphpad inStat software.

The project was approved by the Ethics Research Committee of the Nursing School of the Universidade Federal da Bahia, under register $n^{\circ}$
1.023.774, according to opinion dated April 1, 2015 and was part of a research project on longitudinal study and karyotype/phenotype correlation in genetic syndromes, approved by the Research Ethics Committee, subject to the granting of Free and Informed Consent, in accordance with Resolution $466 / 12$ of the National Health Council ${ }^{12}$ and also following the principles of the Helsinki Convention ${ }^{13}$ and other international documents.

\section{RESULTS}

The summary of data regarding the aging process is presented in Table 1, according to the institutions of origin. Among the patients, the majority (96\%) had the most common karyotype, free trisomy 21 , except one woman with 15/21 chromosomal translocation, with hereditary transmission in five generations by progenitors with the balanced form of the rearrangement.

The group consisted of 15 men and 13 women, predominantly of low socioeconomic status. Among these, 16 were in the age group between 20 and 30 years, and had developed a generally good social relationship.

There was a loss of skills, especially from the fifth decade of life onwards, in which all individuals of this age group had difficulty and slow motor activities. Functional deficits associated with locomotion, physical inactivity, conduct disorders, memory loss and depression, as well as the loss of autonomy were observed in some of the individuals, starting at 25 years old. Depression symptoms were predominantly manifested by individuals from institution B, while the majority of functional difficulties were found in residents of institution $\mathrm{C}$.

During the study period, five of the individuals died due to cardiorespiratory disorders or due to the aggravation of chronic old age diseases associated with depression, and there was a diagnosis of dementia in two. 
Table 1. Down syndrome sample group from three institutions, separated by gender, age, cognitive and functional skills. Data were collected between 2008 and 2017, in the first meeting with each person referred. Salvador, Bahia.

\begin{tabular}{|c|c|c|c|c|}
\hline & $\begin{array}{l}\text { Institution } \mathrm{A} \\
\mathrm{n}(\%)\end{array}$ & $\begin{array}{l}\text { Institution B } \\
\mathrm{n}(\%)\end{array}$ & $\begin{array}{l}\text { Institution } \mathrm{C} \\
\mathrm{n}(\%)\end{array}$ & $\begin{array}{l}\text { Total } \\
\mathrm{n}(\%)\end{array}$ \\
\hline \multicolumn{5}{|l|}{ Sex } \\
\hline Female & $4(36.4)$ & $6(66.7)$ & $3(37.5)$ & $13(46.0)$ \\
\hline Male & $7(63.6)$ & $3(33.3)$ & $5(62.5)$ & $15(53.0)$ \\
\hline \multicolumn{5}{|l|}{ Age (years) } \\
\hline $20-30$ & $8(72.7)$ & $5(55.5)$ & $4(50.0)$ & $17(60.0)$ \\
\hline $31-40$ & $1(9.1)$ & $2(22.2)$ & $2(25.0)$ & $5(18.0)$ \\
\hline$>40$ & $2(18.2)$ & $2(22.2)$ & $2(25.0)$ & $6(21.0)$ \\
\hline \multicolumn{5}{|l|}{ Cognitive activities } \\
\hline Mastery of reading and writing & - & $2(22.2)$ & $1(12.5)$ & $3(11.0)$ \\
\hline Ease of making friends & $8(71.7)$ & $4(44.4)$ & $4(50.0)$ & $16(57.0)$ \\
\hline Autonomy in activities of daily living & - & $1(11.1)$ & - & $1(3.6)$ \\
\hline \multicolumn{5}{|l|}{ Functional characteristics } \\
\hline Speech difficulties & $4(36.4)$ & $3(33.3)$ & - & $7(25.0)$ \\
\hline Difficulties in locomotion & $2(18.2)$ & $2(22.2)$ & $2(25.0)$ & $6(22.0)$ \\
\hline Cognitive and chronic diseases & $3(27.3)$ & - & $2(25.0)$ & $5(18.0)$ \\
\hline Memory loss & - & - & $3(32.5)$ & $3(11.0)$ \\
\hline Often sick & - & - & $1(12.5)$ & $1(3.6)$ \\
\hline Depression Symptoms & - & $5(55.5)$ & $4(50.0)$ & $9(32.0)$ \\
\hline
\end{tabular}

\section{DISCUSSION}

The karyotype results showed a higher prevalence of free trisomy 21 and a low frequency of the unbalanced translocation of this chromosome, in line with literature ${ }^{14}$.

The peculiarities related to the increasing number of people with DS who reach adulthood are not limited to biological issues, but also involve other dimensions of development ${ }^{15}$, such as emotional and social issues, since such changes in the adult phase of people with DS are commonly associated with neurodegeneration processes ${ }^{16}$. The relationships of friendship predominantly observed in individuals attending educational centers support the view that inclusion in the school environment is an important premise for the construction of identity and social relationships. People with intellectual disabilities are able to maintain lasting bonds and the main places where this type of relationship occurs are educational support centers ${ }^{17}$, which highlights the importance of this type of support for development in DS.
The sample group included all adults with DS referred to the program, representing a convenience sample, due to the low demand among adults and elderly people with DS to attend the program, as the majority of care for the syndrome occurs in the early years of childhood. The sample resulted in adults who, at the first meeting, were aged between 20 and 54 years old, similar to previous studies ${ }^{18}$. There were no differences in the severity of manifestations between men and women, however they were more evident at older ages.

The present study supports the fact that there is early deterioration in the aging process in individuals with DS, observing, for example, that three (11\%) of the individuals had symptoms of memory loss, and that according to family information, these symptoms started to appear after the age of 25 . Head et al. ${ }^{19}$ highlight the consequences of chromosome 21 trisomy on the development of AD neuropathology, associated with overexpression of the amyloid precursor protein (APP) gene, precursor of $\beta$-amyloid peptide $(A \beta)$ leading to early-onset amyloid plaque 
formation, neurofibrillary tangles formation, cerebrovascular pathology, white matter pathology, oxidative damage, neuroinflammation and neuron loss. Nichols ${ }^{20}$ highlights the changes associated with $\mathrm{AD}$, such as the phosphorylation and aggregation of the TAU protein, and notes that the action of this protein on the neurodegenerative processes that may affect those with DS is due to the action of the DYRK1A gene involved in hyperphosphorylation, which may lead to neurofibrillary degeneration, making studies of the regulatory enzymes of these processes fundamental for therapeutic purposes.

Each of the institutions that indicated the participants in this study for genetic care had different characteristics. Institutions A and B serve people with disabilities who are assisted by their families and provide educational activities for these individuals and support (lectures, training) for their families. Institution $C$ assists people with disabilities who have been abandoned by their families, and has no program to encourage school education, although the individuals attend special schools. It can be seen, then, that those with DS from each institution have different realities, which are reflected in their relational, emotional and psychological characteristics.

The highest indicators of functional/emotional and psychiatric deficits were observed in institution C, where two $(25.0 \%)$ individuals had walking difficulties; three (37.5\%) memory loss; one $(12.5 \%)$ often fell ill; two $(25.0 \%)$ had cognitive or chronic diseases and four $(50.0 \%)$ had symptoms of depression. These individuals had no contact with their families and some experienced situations of abandonment. According to Viana and Oliveira ${ }^{21}$ it is essential to recognize the role of the family as a therapeutic strategy for the development of people with DS. It is also observed that some of the characteristics presented may be related to the subjective conditions of each individual, such as personality and social stimuli. It was also observed that five $(56.0 \%)$ of the individuals who presented symptoms of depression came from institution B, which provides support to families, highlighting the multifactorial character of the pathology, influenced by several environmental factors.
Nichols ${ }^{20}$ preventively proposes therapeutic measures such as the protection of mitochondrial decline from oxidative stress with antioxidants, sleep regulation, dietary monitoring and vitamin supplementation, among others. Fonseca et al. ${ }^{10}$, considering the occurrence of $\mathrm{AD}$ in this syndrome, emphasize the importance of treatments, pharmacological or not, in reducing cognitive and functional losses, attenuating clinical signs. Health care for adults and elderly people with DS is a matter of priority and should be aimed at maintaining a healthy lifestyle (diet, sleep hygiene and exercise) and developing autonomy for activities of daily living, highlighting measures of self-care, socialization, social and economic inclusion ${ }^{1}$.

From the standpoint of advances in genetics in the treatment of DS, hopes arise with the possibility of the therapeutic application of methodologies derived from the use of the genomic editing tool known as (CRISPR-Cas9), a class of RNA-guided endonucleases known as Cas9, which are extracted from the adaptive immune system of CRISPR microorganisms (clustered regularly interspaced short palindromic repeats), which can be easily directed to virtually any genomic location of choice by a short RNA guide ${ }^{22}$. The use of this tool can lead to the silencing of harmful effect genes, such as those associated with early dementia. This methodology has prospects for evolution, but its long-term effects are still poorly understood and many studies are required before its use as a new therapy.

\section{CONCLUSION}

The analysis of the aging process of adults and the elderly with Down syndrome, performed in this study, allowed the association of specific manifestations with the increased expression of chromosome 21 genes, resulting from chromosomal trisomy. The authors believe that new information on the evolution of dementia disorder in Down syndrome, as well as the implementation of compensatory responses that may benefit nervous system functioning, may provide opportunities to develop interventions aimed at delaying or suppressing the manifestation of this disorder. 


\section{REFERENCES}

1. Brasil. Ministério da Saúde, Secretaria de Atenção à Saúde, Departamento de Ações Programáticas Estratégicas, Diretrizes de atenção à pessoa com Síndrome de Down. Brasília, DF: Ministério da Saúde; 2013.

2. Kruszka P, Porras AR, Sobering AK, Ikolo FA, La Qua S, Chung BHY, et al. Down syndrome in diverse populations. Am J Med Genet Part A. 2017;73:42-53.

3. Da Rosa ERA. Os idosos com síndrome de Down e a exclusão social na velhice: um estudo de caso [dissertação]. Brasília, DF: Universidade católica de Brasília; 2015.

4. Van Buggenhout GJCM, Trommelen JCM, Schoenmaker C, de Bal C, Veerbeck JJ, Smeets DS, et al. Down Syndrome in a population of elderly mentally retarded patients: Genetic-Diagnostic survey and implications for medical care. Am J Med Genet. 1999;85:376-84.

5. Lopes BS, Vianna LG, Moraes CF, Carvalho GA, Alves VP. A Síndrome de Down e o processo de envelhecer: revisão sistemática. Rev Kairós. 2014;17(4):141-55.

6. Hithersay R, Startin CM, Hamburg S, Mok KY, Hardy J, Fisher EMC, et al. Association of dementia with mortality among adults with Down syndrome older than 35 years. JAMA Neurol. 2018;76(2):152-60.

7. Arking R. Biologia do envelhecimento: observações e princípios. Tradução: Feliciano AI; revisão Duarte FAM. Ribeirão Preto : FUNPEC; 2008.

8. Hopkins K. Chromosome 21 genes in Down syndrome and development. J NIH Res. 1995;7:29-30.

9. Bettini-Pereira RA, Blascovi-Assis SM, Nunes R. Bioética e síndrome de Down: pesquisa com cuidadores de pacientes adultos. Cad Pós-Grad Distúrb Desenvolv. 2015;15(2):18-28.

10. Fonseca LM, Navatta ACR, Bottino CMC, Miotto EC. Cognitive rehabilitation of dementia in adults with Down syndrome: a review of nonpharmacological interventions. Dement Geriatr Cogn Disord Extra. 2015;5(3):330-40.

11. McGowan J, Simons A, Schimd M, Switzland S, Karger AG. ISCN 2016: An International System for Human Cytogenetic Nomenclature. [Place unknown]: Karger; 2016.
12. $21^{a}$ Resolução 466/12 de 12 de dezembro de 2012. Aprova diretrizes e normas regulamentadoras de pesquisa envolvendo seres humanos. Saúde. Legis. 2012. Disponivel em: http://bvsms.saude.gov.br/bvs/ saudelegis/cns/2013/res0466_12_12_2012.html

13. World Medical Association. Declaration of Helsinki. Ethical principles for medical research involving human subjects [Internet]. [Place unknown]: WAM; 2008 [acesso 01 nov. 2013]. Disponível: http://www. wma.net/en/30publications/10policies/b3/17c.pdf

14. Dias FL. O Treino da condição física na Trissomia 21: estudo de caso com aplicação de um programa específico [dissertação]. Porto: Universidade do Porto; 2016.

15. Grieco J, Pulsifer M, Seligsohn K, Skotko B, Schwartz A, Down syndrome: Cognitive and behavioral functioning across the lifespan. Am J Med Genet Part C. 2015;169:135-49.

16. Andrade JFCM, Adultos com síndrome de Down e seus familiares cuidadores: caracterização, qualidade de vida e estresse [dissertação]. Juíz de Fora: Universidade Federal de Juiz de Fora; 2017.

17. Annus T, Wilson LR, Young TH, Acosta-Cabronero J, Fryer TD, Cardenas-Blanco A. The pattern of amyloid accumulation in the brains of adults with Down syndrome. Alzheimers Dement. 2016;12:538-45.

18. Andrade JFCM, Silva NLP. Adultos com síndrome de Down por eles mesmos: relatos de suas vivências. Psicol Pesqui. 2018;12:1-9.

19. Head E, Lott IT, Wilcock DM, Lemere CA. Aging in Down Syndrome and the development of Alzheimer's Disease neuropathology. Curr Alzheimer Res. 2016;13(1):18-29.

20. Nichols TW. Hyperphosphorylation of Tau Protein in Down's Dementia and Alzheimer's Disease: Methylation and Implications in Prevention and Therapy. J Alzheimers Dis Parkinsonism. 2014;4(5):1-8.

21. Viana LP, Oliveira EMP. Influência do entorno familiar no desempenho comunicativo de crianças com Síndrome de Down. Rev CEFAC. 2015;17(1):177-83.

22. Hsu PD, Lander ES, Zhang F. Development and Applications of CRISPR-Cas9 for Genome Engineering. Cell. 2014;157:1262-78. 